пространства, создание механизмов взаимодействия органов власти и общества, способствует правовой осведомленности граждан, формированию правовой грамотности и соответственно защищенности граждан в вопросе обеспечения и защиты прав.

$$
* * *
$$

1. Конституция Российской Федерации (принята на всенародном голосовании 12.12.1993)

2. Травников Н.О. Конституционно-правовой анализ понятия «право на информацию» // Российский юридический журнал. 2014. № 4. С. 18 - 22.

3. Об информации, информационных технологиях и о защите информации: федеральный закон от 27.07.2006 № 149-Ф3 // Российская газета. 2006. № 165.

4. Об обеспечении доступа к информации о деятельности государственных органов и органов местного самоуправления: федеральный закон от 09.02.2009 № 8-Ф3 // Российская газета. 2009. № 25.

5. О порядке рассмотрения обращений граждан Российской Федерации: федеральный закон от 02.05.2006 № 59-Ф3 // Российская газета. 2006. № 95.

6. Козловская О.А. К вопросу о современных правовых гарантиях, формах и сложностях реализации права граждан на доступ к информации о деятельности органов власти и местного самоуправления // Пробелы в российском законодательстве. 2016. № 8 .

7. Жарова А.К. Гражданское общество: системный подход // Информационное право: актуальные проблемы теории и практики / под ред. И.Л. Бачило. М. 2009. 126 с.

\title{
Белов А.А.
}

К вопросу о необходимости внесения дополнений и изменений в Кодекс Волгоградской области об административной ответственности от 11 июня 2008 г. № 1693-ОД мер обеспечивающих производство по делам об административных правонарушениях

ФГАОУ ВО «Волгоградский государственньй университет» (Россия, Волгоград)

doi: 10.18411/lj-11-2019-194

idsp: ljournal-11-2019-194

\section{Аннотация}

В данной статье автором рассматриваются вопросы классификации мер административного принуждения, применяемые в практической деятельности должностными лицами органов местного самоуправления. Автор проанализировал вопросы, связанные с практическим применением этих мер. Также автор предлагает внести в Кодекс Волгоградской области об административной ответственности от 11 июня 2008 г. № 1693-ОД меры, обеспечивающие производство по делам об административных правонарушениях, т.к. это позволит значительно сократить срок рассмотрения материалов об административных правонарушениях и более существенно закрепить доказательную базу по этим правонарушениям.

Ключевые слова: административное принуждение; классификация мер административного принуждения; виды мер административного принуждения; меры административно-процессуального обеспечения; меры, обеспечивающие производство по делам об административных правонарушениях; органы исполнительной власти Волгоградской области; органы местного самоуправления Волгоградской области.

\section{Abstract}

In this article, the author considers the classification of administrative coercive measures used in practice by officials of local governments. The author analyzed issues related to the practical application of these measures. The author also suggests introducing into the Volgograd Region Code of Administrative Responsibility No. 1693-OD dated June 11, 2008 measures that ensure proceedings on administrative offenses, as this will 
significantly reduce the time for consideration of materials on administrative offenses and more significantly consolidate the evidence base on these offenses.

Keywords: administrative coercion; classification of administrative coercive measures; types of administrative coercive measures; measures of administrative procedure; measures to ensure administrative proceedings; executive authorities of the Volgograd region; local authorities of the Volgograd region.

Административное принуждение является одной из составляющих разновидностей государственного принуждения. На практике, административное принуждение может являться основным средством реализации в правоприменительной деятельности специально уполномоченных субъектов (в нашем случае иеются ввиду должностные лица органов исполнительной власти волгоградской области, а также должностные лица органов местного самоуправления).

Значительной число ученых-административистов, в настоящее время пришли к выводу о том, что целесообразно классифицировать меры административного принуждения, применяемые специально уполномоченными субъектами на четыре вида мер, а именно:

1. Административно-предупредительные меры.

2. Административно-пресекательные меры.

3. Меры административно-процессуального обеспечения (т.е. меры, которые обеспечивают производство по делам об административных правонарушениях).

4. Административные наказания.

Можно рассматривать и пятый вид мер административного принуждения, а именно - административно-восстановительные меры. Но данный вид мер можно рассматривать в настоящее время лишь условно.

Необходимо отметить о том, что до принятия КоАП РФ согласно «старого» КоАП РСФСР ряд ученых рассматривали данный вид административного принуждения, который потерял свою актуальность в связи с изменением административного законодательства. Согласно ст. 4.7 КоАП РФ, которая предусматривает возмещение имущественного ущерба и морального вреда, причиненного административным правонарушением данные вопросы разрешаются судом в порядке гражданского судопроизводства. Исходя из этого, напрашивается однозначный и категоричный вывод, что существующие административно-правовые отношения переходят в гражданско-правовые отношения.

Глубоко исследовав нормативно-правовую базу Российской Федерации, а также правоприменительную практику органов местного самоуправления можно сделать вывод о том, что должностные лица местного самоуправления из четырех видов административного принуждения имеют право применять только два вида:

- Административные наказания.

- Меры административно-процессуального обеспечения (т.е. меры, которые обеспечивают производство по делам об административных правонарушениях).

Автор считает необходимым внести изменения в Кодекс Волгоградской области об административной ответственности от 11 июня 2008 г. № 1693-ОД с целью приведения административного законодательства Волгоградской области в соответствие с Федеральным законодательством (с КоАП РФ от 30.12.2001 г. № 195Ф3). Необходимость внесения этих изменений обусловлена и связана с совершенствованием на практике правоприменительной деятельности субъектами административной власти органов исполнительной власти Волгоградской области, а также органом местного самоуправления Волгоградской области. 
Применение мер административно-процессуального обеспечения при производстве дел об административных правонарушениях закрепленных в Кодексе Волгоградской области об административной ответственности от 11 июня 2008 г. № 1693-ОД позволит значительно сократить срок рассмотрения административных материалов по существу, а также более значимо и четко закрепить доказательную базу по фактам совершенных данных административных правонарушений.

При этом необходимо заметить, что применение мер административнопроцессуального обеспечения предлагаемых в Кодексе Волгоградской области об административной ответственности от 11 июня 2008 г. № 1693-ОД никаким образом не противоречит и не вступает в правовую коллизию с нормами мер обеспечения производства по делам об административных правонарушениях, которые закреплены в КоАП РФ от 30.12.2001 г. № 195-Ф3.

Автор предлагает внести в Главу 2. «Возбуждение и рассмотрение дел об административных правонарушениях» Кодекса Волгоградской области об административной ответственности от 11 июня 2008 г. № 1693-ОД следующие изменения:

Ввести ст. 2.11 «Применение мер административно-процессуального обеспечения при производстве по делам об административных правонарушениях».

Меры обеспечения производства по делам об административных правонарушениях.

В целях предупреждения, пресечения, административного правонарушения, установления личности нарушителя, грамотного составления протокола об административном правонарушении, осуществления быстрого и верного рассмотрения дела об административном правонарушении, а также исполнения принятого по делу вынесенного постановления должностное лицо органа исполнительной власти Волгоградской области или же местного самоуправления вправе, в пределах своих полномочий, применять установленные меры административно-роцессуального обеспечения производства по делам об административных правонарушениях:

1) Осмотр принадлежащих юридическому лицу или индивидуальному предпринимателю помещений, территорий,объектов а также находящихся там вещей и документов.

Осмотр принадлежащих юридическому лицу или индивидуальному предпринимателю используемых для осуществления предпринимательской деятельности помещении, территорий, объектов, находящихся там вещей и документов может производиться должностными лицами, уполномоченными составлять протоколы об административных правонарушениях в соответствии с настоящим Кодексом.

Осмотр принадлежащих юридическому лицу или индивидуальному предпринимателю помещений, территорий,объектов и находящихся там вещей и документов осуществляется в присутствии представителя юридического лица, индивидуального предпринимателя или его представителя, а также в присутствии двух понятых либо с применением видеозаписи.

O произведённом осмотре принадлежащих юридическому лицу или индивидуальному предпринимателю помещений, территорий,объектов и находящихся там вещей и документов составляется протокол, в котором указываются дата и место его составления, должность, фамилия и инициалы лица, составившего протокол, сведения о соответствующем юридическом лице, а также о его законном представителе либо об ином представителе, об индивидуальном предпринимателе или о его представителе, об осмотренных территориях и помещениях, о виде, их количестве.

Материалы, полученные при осуществлении осмотра с применением фото- и киносъемки, иных установленных способов фиксации вещественных доказательств, прилагаются к соответствующему протоколу. 
Протокол об осмотре принадлежащих юридическому лицу или индивидуальному предпринимателю помещений, территорий и находящихся там вещей и документов подписывается должностным лицом, его составившим, законным представителем юридического лица, индивидуальным предпринимателем либо в случаях, не терпящих отлагательства, иным представителем юридического лица или представителем индивидуального предпринимателя, а также понятыми в случае их участия. В случае отказа законного представителя юридического лица или иного его представителя, индивидуального предпринимателя или его представителя от подписания протокола в нем делается соответствующая запись. Копия протокола об осмотре принадлежащих юридическому лицу или индивидуальному предпринимателю помещений, территорий и находящихся там вещей и документов вручается законному представителю юридического лица или иному его представителю, индивидуальному предпринимателю или его законному представителю.

2) Изъятие вещей и документов.

Изъятие вещей, явившихся предметами или орудиями совершения административного правонарушения, и документов, имеющих значение доказательств по делу об административном правонарушении и обнаруженных на месте совершения административного правонарушения осуществляется должностными лицами уполномоченными составлять материалы по делам об административных происшествиях.

В случае необходимости при изъятии вещей и документов применяются фото- и киносъемка, иные установленные способы фиксации вещественных доказательств.

В случае если изымаются документы, с них изготавливаются копии, которые заверяются должностным лицом, изъявшим документы, и передаются лицу, у которого изымаются документы, о чем делается запись в протоколе. В случае, если невозможно изготовить копии или передать их одновременно с изъятием документов, указанное должностное лицо передает заверенные копии документов лицу, у которого были изъяты документы, в течение 10 дней после изъятия, о чем делается запись в протоколе. В случае если по истечении 10 дней после изъятия документов, заверенные копии документов не были переданы лицу, у которого изъяты документы, заверенные копии документов в течение 3 дней должны быть направлены по почте заказным почтовым отправлением, о чем делается запись в протоколе с указанием номера почтового отправления. Копии документов направляются по адресу места нахождения юридического лица или же по адресу места жительства физического лица, указанного в протоколе.

Материалы, полученные при изъятии вещей и документов с применением фотои киносъемки, иных установленных способов фиксации вещественных доказательств, прилагаются к соответствующему протоколу.

Протокол об изъятии вещей и документов подписывается должностным лицом, его составившим, лицом, у которого изъяты вещи и документы, а также понятыми в случае их участия. В случае отказа лица, у которого изъяты вещи и документы, от подписания протокола в нем делается соответствующая запись. Копия протокола вручается лицу, у которого изъяты вещи и документы, или его законному представителю.

3) Арест товаров и иных вещей.

Арест товаров и иных вещей, которые явились орудиями совершения или же предметами административного правонарушения, заключается в составлении описи указанных товаров и иных вещей с объявлением лицу, в отношении которого применена данная административно-процессуальная мера обеспечения производства по делу об административном правонарушении, либо его законному представителю о запрете распоряжаться (а в случае необходимости и пользоваться) ими и применяется в 
случае, если указанные товары и иные вещи изъять невозможно и (или) их сохранность может быть обеспечена без изъятия.

Арест товаров и иных вещей осуществляется должностными лицами, указанными в настоящем Кодексе, в присутствии владельца вещей, а также в присутствии двух понятых либо с применением видеозаписи.

В случаях, не терпящих отлагательства, арест вещей может быть осуществлен в отсутствие их владельцев.

Об аресте товаров и иных вещей составляется соответствующий протокол. В протоколе об аресте товаров и иных вещей указываются дата и место его составления, должность, фамилия и инициалы лица, составившего протокол, сведения о лице, в отношении которого применена данная административно-процессуальная мера обеспечения производства по делу об административном правонарушении, а также и о лице, во владении которого находятся товары и иные вещи, на которые накладывается арест, их опись и идентификационные признаки, а также делается запись о применении фото- и киносъемки, иных установленных способов фиксации вещественных доказательств.

В случае необходимости товары и иные вещи, на которые наложен арест, упаковываются и (или) опечатываются.

Копия протокола об аресте товаров и иных вещей вручается лицу, в отношении которого применена данная мера обеспечения производства по делу об административном правонарушении, либо его законному представителю.

$$
* * *
$$

1. «Кодекс Российской Федерации об административных правонарушениях» от 30.12.2001 N 195-Ф3 (ред. от 12.11.2019).

2. «Кодекс Волгоградской области об административной ответственности» от 11 июня 2008 г. № 1693-ОД.

3. М.И. Еропкин. О классификации мер административного принуждения. Сб. «Вопросы советского административного права на современном этапе». М., 1963 г.

4. Попова, Н. Ф. Административное право: учебник и практикум для СПО / Н. Ф. Попова. - 4-е изд., испр. и доп. - Москва: Издательство «Юрайт», 2019.

5. Муниципальное право России: учебник для бакалавриата и магистратуры / А. Н. Кокотов [и др.] ; под ред. А. Н. Кокотова. — 5-е изд., перераб. и доп. — Москва: Издательство «Юрайт», 2019.

6. Советское административное право: учебник. / под общей редакцией Ю. М. Козлова. - Москва: Издательство «Юридическая литература», 1985.

\section{Богомолова Н.А., Фирсова Н.В. \\ Условия приобретения права собственности по давности фактического владения} ФГБОУ ВО Башкирский государственный университет doi: 10.18411/lj-11-2019-195

(Россия, Уфа)

idsp: ljournal-11-2019-195

\section{Аннотация}

Данная статья посвящена рассмотрению особенностей приобретения права собственности по давности фактического владения. В частности, проанализированы вопросы и условия возникновения права собственности по давности фактического владения и современное состояние института приобретательной давности.

Ключевые слова: приобретательная давность, давностное владение, добросовестность владения, открытое владение.

Abstract

This article is devoted to consideration of features of acquisition of the property right on prescription of actual possession. In particular, the issues and conditions of the emergence 